\title{
Biologicalutilization Of Water Hyacinth (Eichhornia crassipes) FOR Production Of Value Added Products
}

\author{
Kavitha $\mathbf{R}^{1^{*}}$, Manikandan $\mathbf{M}^{1}$, Sanjai Gandhi $\mathbf{K}^{2}$,Natesan Vijayakumar ${ }^{3}$ \\ ${ }^{1}$ Department of Biotechnology, Periyar University PG Extension Centre, Dharmapuri - 636 701, Tamil Nadu, \\ India. \\ ${ }^{2}$ Department of Geology, Periyar University, PG Extension Centre, Dharmapuri - 636 701, Tamil Nadu, India. \\ ${ }^{3}$ Department of Biochemistry and Biotechnology, Faculty of Science, Annamalai University, Annamalainagar- \\ 600802, Tamil Nadu, India.
}

\footnotetext{
*Address forCorresponding author:

Dr. Kavitha. R

Associate Professor \& Head

Department of Biotechnology,

Periyar University PG Extension Centre,

Dharmapuri - 636 701, Tamil Nadu, India.

Email: erokavi_vasu@yahoo.com
} 


\begin{abstract}
Water hyacinth (Eichhornia crassipes) is an invasive variety of free - buoyant plant, its suffocate water bodies in tropical areas. In the river, Water hyacinth causes an effect on human health so, as to prevent or reduce this plant build up in the river, we have to overcome this issue in a commercial and economic means. So, we have to maintain the clean India movement and Green India dogma one step ahead to clean Rivers and make them free from Water hyacinth. This also helps to conserve the river ecosystem. And for that, we should also have an idea about the characteristics and constituents of Water hyacinth. Its capacity for growth and dissemination provokes major protection of the problems and is an emerging environmental issue Water hyacinth motivated this article. The assessment of this review study is to recycle the Waterhyacinth biomass for the production of biogas, biofertilizer, biostimulants etc., by using feasible technologies to promoting 'ecofriendly organic farming practices for the betterment of our farmers. At the outset, the potential impact of this review is to shed new light on the better use of feebly studied Water hyacinth for the enhancement of agriculture production through organic farming. This gives invaluable products like biogas, biofertilizers, and uses like biostimulants, phyto-remediation and medicinal uses as discussed in this study.
\end{abstract}

Key words:Eichhornia crassipes; Water hyacinth; Biogas; Biofertilizer; Biostimulants; Natural wastes 


\section{Introduction}

India is one of the most important countries in the world, with a diverse crop growing in water segments such as lakes, ponds, rivers, and traces of water bodies. As a result, cleaning and altering excess herb is necessary to protect aquatic life [1]. Water hyacinth (WH-Eichhornia crassipes) is free-afloat perpetual hydrophytes that belong to the family Pontederiaceae. The tidy is recognized as Akasa or Vengaya Tamara in Tamil, Kola vazha in Malayalam Pisachitha tamara in Telugu, and Jal khumbe in Hindi. In the Asian subcontinent, WH is named as "Terror of Bengal". The plants are thick, broad, ovate, and glossy and float beyond the water exterior. They contain spongy, long and bulbous stalks. It has a quick development pace, extreme green mat over inert water bodies like as lakes, waterways, streams, ponds, and backwater and is recognized by its purple-coloured flowers and shinning strong leaves [2]. The plant euryhaline, which tolerates both clean and aquatic water; therefore it spreads at a startling high quality of biomass production [3, 4].

The plant $\mathrm{WH}$ required a minimum $120^{\circ} \mathrm{C}$ temperatures and a maximum $350^{\circ} \mathrm{C}$ of growth and its $\mathrm{pH}$ tolerance lies between 5 and 7.5. The ecological hazards allied with these plant life are despoiled water value, and radical changes in the plant and animal community, radiance and oxygen diffusion are cruelly partial diminution in water faction etc., Other ecological hazard take in congestion of irrigation, hydropower, and water supply ways, the difficulty of water convey, obstruction of canal and rivers cause flood $[5,6]$.

The influence of mechanical and economic progress on the natural environment may lead to deterioration of the social and cultural environment. As a result, the environment must be examined in a larger sense, taking into account the surrounding parts as well as their interconnections [7]. The impact of mechanical and electrical systems The Environment (Protection) Act of 1986 defines environment as all of an organism's physical and natural environmental components, as well as their interactions [8]. Other than live organisms and materials, the environment is defined as "the sum of all water, terrestrial, and air and interconnections that persist surrounded by them and with human people." Fig. 1.0 effectively illustrates the concept of environment.

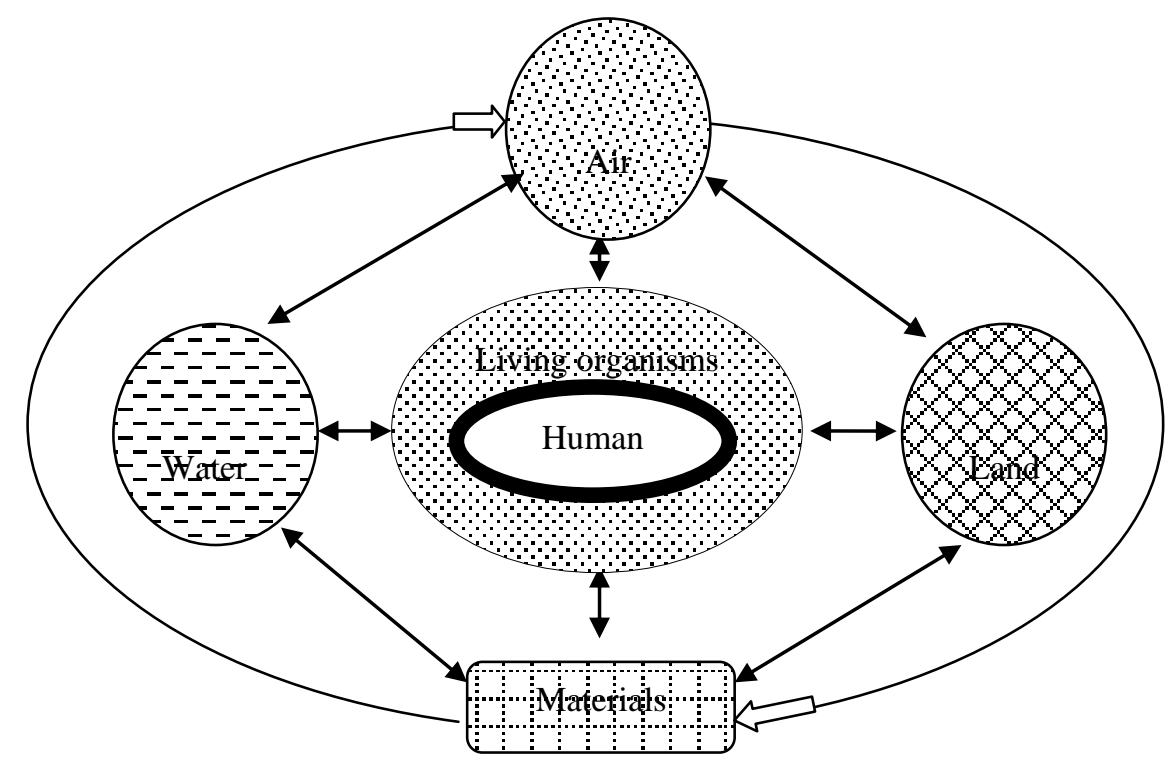


Figure1. Environments are made up of water, air, land, living beings, and materials, as well as their interactions [9].

Draw a picture of a human's habitat. The water, air, and land that surround us form our environment and have a direct impact on us. At the same time, we have an influence on the environment due to resource exploitation or misuse, as well as pollution of the water, air, and land. Microorganisms, animals, and flora, as well as manmade constructions in the environment, have all had direct or indirect bidirectional interactions with us [10]. The environment is created by all of these components and their interactions. The threat posed by WH is particularly concerning for water resources that are highly dynamic, such as irrigation water [11, 12].

In the south Asia pacific region, WH encompasses grounds considerable damage to restricted domestic surface water quality and domestic biodiversity [13]. WH proliferation worldwide geo and biological organize scheme is approximately sketchy to have a cost of few million of U.S. dollars [14].WH harvested handling has been put into the valuable negative image for WH in several countries and their demerits following as, Table 1.

Table 1. Demerits and negative image for Water hyacinth

\begin{tabular}{|c|c|c|c|}
\hline S.No. & Demerits & Description & Reference \\
\hline 1. & $\begin{array}{l}\text { Reduction to } \\
\text { biodiversity }\end{array}$ & $\begin{array}{l}\text { WH is a floating typed aquatic plant suppressing the } \\
\text { development of local plants and some native fishes and } \\
\text { prevents the abundance of phytoplankton under huge } \\
\text { mats. }\end{array}$ & {$[15]$} \\
\hline 2. & $\begin{array}{l}\text { Blocking oxygen } \\
\text { depletion and Reduced } \\
\text { water quality }\end{array}$ & $\begin{array}{l}\text { In the aquatic ecosystem, WH plays a vital role for block } \\
\text { the light and oxygen to the marine organisms, which } \\
\text { affect the primary production of planktons and microbes } \\
\text { and also it leads to death for fishes. Furthermore, low } \\
\text { dissolved oxygen conditions stimulate the release of } \\
\text { phosphorus from the silt, hastening eutrophication and } \\
\text { perhaps leading to a rise in WH. The world's most } \\
\text { epidemic weed, WH, also causes alterations in water } \\
\text { chemistry. }\end{array}$ & {$[16,17]$} \\
\hline 3. & Water pollution & $\begin{array}{l}\text { The plant's quick growth and spread into new areas is } \\
\text { attributed to its ability to move easily with water flows, } \\
\text { winds, or other unintentional techniques such as fishing } \\
\text { nets and boats. The plant attacked streams, canals, ponds, } \\
\text { lakes, dams, and other bodies of freshwater. Water } \\
\text { transit is hampered. }\end{array}$ & [18] \\
\hline 4. & Plastics debris in water & $\begin{array}{l}\text { WH often collects and forms large plant patches, which } \\
\text { also contain plastic trash. Plastic transport in such rivers } \\
\text { may be predominantly influenced by vegetation } \\
\text { dynamics, rather than hydro-meteorological cycles such } \\
\text { as outflow, water level, flow speed, or wind velocity. }\end{array}$ & [19] \\
\hline
\end{tabular}




\begin{tabular}{|c|c|l|c|c|}
\hline \multirow{5}{*}{5.} & \multirow{2}{*}{$\begin{array}{c}\text { Blockage of } \\
\text { waterways and streams } \\
\text { causing flooding }\end{array}$} & $\begin{array}{l}\text { WH may develop so thickly that a human being can walk } \\
\text { on it. When it takes root in streams and canals, it may } \\
\text { grow so dense that it creates a herbivorous barrage, } \\
\text { causing damage and posing a flood danger. } \\
\text { Also, water running to farm fields and hydroelectric } \\
\text { turbines is obstructed, causing significant economic and } \\
\text { environmental impact. }\end{array}$ & {$[18,15]$} \\
\hline 6. & evapotranspiration rate & $\begin{array}{l}\text { Evapotranspiration rate has been increased from water } \\
\text { body with aquatic plants compared to evaporation from } \\
\text { an open-surfaced water body }\end{array}$ & {$[6]$} \\
\hline 7. & Effect on human health & $\begin{array}{l}\text { WH causes the significant public medical issues like } \\
\text { malaria, schistosomiasis and lymphatic filariasis. }\end{array}$ & {$[18]$} \\
\hline
\end{tabular}

\section{Production of value added products and applications of WH}

\section{Production of Biogas}

In marine environments, weeds are a basin reservoir of both energy and nutrients [20]. The harvest and anaerobic digestion might permit for both the nutrients and energy that are detained in an unnatural manner which would ensure that they are taken away from the reservoir deposition and value-added reprocess. Organic biogas is a gas mixture that results from the anaerobic fermentation of organic waste by methanogenic bacteria. WH's potential as a raw material for biogas assembly has been the subject of a number of studies. On a laboratory scale, the anaerobic co-digestion of WH in conjunction with particle and elephant grass for biogas invention was calculated. The investigation revealed that co-digestion of WH, cow dunk, and organic leftovers resulted in a greater biogas output [21].WH contains $64 \%$ methane and can be used for biogas invention and water decontamination. It has an excellent source of biomass [22].

\section{Production of Biofertilizer}

The farmers were willing to employ chemical fertiliser as it yields a great amount of crops. However, scientists eventually realised that chemical fertiliser had an adverse effect on sediment soil fertility and kills beneficial microbes. Chemical fertilisers contaminate the ecosystems of the air, soil, and water. Researchers have discovered that "Biofertilizer" is an excellent alternative to chemical fertilisers for avoiding this problem [23]. The better presentation of the soil approached with WH as for the higher rate of germination due to improve the soil fertility by releasing nutrient content such as nitrogen and phosphorus it had assimilated from its surroundings and preparation oflivingcells or effective microorganism. It would have intensified the proffering of phytohormones like gibberellins and auxins [24]. WH applied to seeds, plants, or to the rhizosphere it refashioned concomitantly, and unquestionably the bacterial pursued of the rhizosphere, propounded urge that they were ideal for organic matter and simperishable farming [25-27].

\section{Biostimulants}

The plant biostimulants also called phytochemicals/ insignificant metabolites delineate as an organic material which is consist gatered and the substances along with alkaloids flavonoids, terpenoids, and phenolic compounds ensue spontaneously in plants [28]. The positive characteristic of biostimulants keep popularizes the monetary cultivation of deserted and underutilized domestic leafy vegetables. Numerous undervalued and 
underutilised vegetables have the ability to add variety to the human diet and increase food extension levels by educating people about agro-food systems.

WH is more sustainable and resilient [29]. Natural biostimulants derived from sewage muck, chicken feathers, WH condensed distiller's soluble enzymatic hydrolysate, carob germ enzymatic extract, rice grain extract, and other sources have recently been used. The enzymatic hydrolysis approach to natural xenobiotic contamination of sediment soil was a widely used containment method for speeding up and stimulating the breakdown of the stated xenobiotics in sediment soil.The xenobiotics-tolerant microorganisms are fascinated and included by the lower molecular weight proteins found in abundance in these biostimulants, extending their multiplication and the biochemical exercise action of the sediment soil, and thus accelerating the disintegration of the contamination in the soil [30-33].

The biostimulants continue practiced in cramped quantities to the plants enhanced the growth of plants and sediment microorganisms, enhanced the chemical, physical, and microbial aspect of cultivated sediment soil, and condensing the colony on chemical fertilizers. WH yield have been focus into the scared use in various countries and their product applications following as Table 2.

Table 2. Possible applications of Water Hyacinth

\begin{tabular}{|c|c|c|c|}
\hline S. No. & Applications & Description & Reference \\
\hline 1. & $\begin{array}{l}\text { Industrial and } \\
\text { Environment } \\
\text { applications }\end{array}$ & $\begin{array}{l}\text { Paper making- WH is utilized for cigar covering production } \\
\text { by utilizing fibrous tissue of } \mathrm{WH} \text { mixed with jute. } \\
\text { Yarn rope - The fibres present in } \mathrm{WH} \text { can be used to produce } \\
\text { ropes. } \\
\text { Water purification -The roots of } \mathrm{WH} \text { has been absorbed } \\
\text { various types of heavy metals such as } \mathrm{Cu}, \mathrm{Cd}, \mathrm{Ni}, \mathrm{Ag}, \mathrm{Cr}, \mathrm{Zn} \text {, } \\
\mathrm{Mg}, \mathrm{Mn} \text { also create a suitable environment for the growth of } \\
\text { aerobic microorganisms. }\end{array}$ & {$[34]$} \\
\hline 2. & $\begin{array}{l}\text { Charcoal } \\
\text { briquetting }\end{array}$ & $\begin{array}{l}\text { The pyrolysis from the WH is used to create charcoal } \\
\text { briquetting in small-scale industries. }\end{array}$ & {$[15]$} \\
\hline 3. & Seed adhesion & $\begin{array}{l}\text { WH is directly used as green manure for many plants. The } \\
\text { root portion has been promoting the growth and yield of the } \\
\text { vegetables. Naturally, WH has a moisture-containing capacity } \\
\text { and its leads to the higher moisture-holding capacity of the } \\
\text { soil. }\end{array}$ & {$[35]$} \\
\hline 4. & Pollution control & $\begin{array}{l}\text { Now day pollution is the biggest problem for every country, } \\
\text { The waste effluents from the industries, mixed with water, } \\
\text { which leads to water pollution. WH is important in the } \\
\text { removal of pollutants from the water, including as BOD, } \\
\text { phosphorus, and metals. }\end{array}$ & {$[36]$} \\
\hline 5. & $\begin{array}{l}\text { Phyto- } \\
\text { remediation }\end{array}$ & $\begin{array}{l}\text { Industrial effluent is one of the major sources of water } \\
\text { pollution. The effluents contain numerous amounts of dyes. } \\
\text { WH can remove the dyes from the water. It has been absorbed } \\
\text { the dyes from the water and removes. Also, the phyto- }\end{array}$ & [37-38] \\
\hline
\end{tabular}




\begin{tabular}{|c|c|c|c|}
\hline & & $\begin{array}{l}\text { remediation process is used to remove some heavy metals } \\
\text { from the water. }\end{array}$ & \\
\hline 6. & $\begin{array}{c}\text { Energy } \\
\text { production }\end{array}$ & $\begin{array}{l}\text { Recent studies reveal that WH has been used for the } \\
\text { production of bio-fuel and ethanol. }\end{array}$ & [39] \\
\hline 7. & Medicinal uses & $\begin{array}{l}\text { In India, WH has long been used to cure skincare and goitre. } \\
\text { The WH extracts were converted into a therapeutically } \\
\text { acceptable solvent and used in the clinical therapy of lipid } \\
\text { dysregulation or the treatment of fatty liver patients. It has } \\
\text { been discovered to be a very effective health-care product. }\end{array}$ & [40-41] \\
\hline 8. & $\begin{array}{l}\text { Anti-oxidative } \\
\text { properties }\end{array}$ & $\begin{array}{l}\text { The apical oxidative potential was noticed for freeze- } \\
\text { dried WH leave extract. The outcomes demonstrated the } \\
\text { capability of this plant as another option and } \\
\text { advantageous ease crude material for anti-oxidizing } \\
\text { agent recovery. The leaf extracts of WH have been set up to } \\
\text { have phyto-chemicals with strong antioxidant and hepato } \\
\text { protective exercises. The ability of WH extracts to reduce } \\
\text { blood lipid levels in vitro has been demonstrated, along with } \\
\text { the prevention of fatty liver. }\end{array}$ & {$[42]$} \\
\hline 9. & $\begin{array}{l}\text { Anti-aging } \\
\text { efficacy }\end{array}$ & $\begin{array}{l}\text { Potential of extracts of WH in anti-aging adequacy by } \\
\text { DPPH radical scavenging assay and DNA damage } \\
\text { inhibition assay. There was an increase in DPPH radical } \\
\text { scavenging and DNA damage inhibition capacity. }\end{array}$ & [43] \\
\hline 10. & $\begin{array}{l}\text { Anti-cancer } \\
\text { properties }\end{array}$ & $\begin{array}{l}\text { Because of the existence of several cancer-fighting } \\
\text { chemicals in WH, it has been reported to have } \\
\text { anticancer potential. It is also reported to have antifungal, } \\
\text { antibacterial, and anti-inflammatory activities (fungicidal and } \\
\text { bactericidal actions). It's commonly used to cure cholera, sore } \\
\text { throats, and snake bites, as well as as a hair scent. WH has } \\
\text { also been shown to have larvicidal and wound-healing effects. }\end{array}$ & {$[44,45]$} \\
\hline
\end{tabular}

\section{Conclusion}

In this study from the above literature, we come to the following conclusions regarding Water hyacinth. It has been revealed that the assimilation of WH after its autoclave pre-treatment together with cow dung is a resourceful way to augment the biogas/ $\mathrm{CH}_{4}$ yield rather than organic $\mathrm{WH}$. The combination of pre-treated $\mathrm{WH}$ the length of using cow dung can be optional during bio-methanation. From that different aspect, the recognition of key microbial commune further spread out our thoughts of the organic microbial metabolic conduit and multi-faceted biological gathering during the Bio-methanation progression.

1. Removing WH promotes cleaning of the river.

2. It reduces harm to the ecosystem.

3. It is also can be used in producing bio-products as discussed. 
The cheap bio products produce by this protocol and elimination of risk in handling of chemical biofertilizers and biostimulants. From this study we can conclude that a commercial method should be developed to control and removing of WH. As a result, there is a significant need to adapt agricultural systems by adopting an alternative environmentally pleasant and effective source of soil additives in order to investigate "best out of trash." As a result, exploitation may become a way of life for it.

\section{Declarations}

Not applicable

\section{Funding details}

This work was supported by the Tamil Nadu State Council for Science and Technology (TNSCST

S\&T) project under Grant number TNSCST/STP/ES/02/VR/2018-2019/9254

\section{Conflicts of interest}

None

\section{References}

1. Chandrajeet Verma., Ashish Kumar., Shweta Pal., Shashwat Sinha., Ashish Kumar Singh., Aniruddha Jaiswal., and Rajiv Prakash.Polyaniline stabilized activated carbon from Eichhornia Crassipes: Potential charge storage material from bio-waste. Renew Energy.,2020,162: 2285-2296. doi: 10.1016/j.renene.2020.09.135

2. Unpaprom, Y., Pimpimol, T., Whangchai, K., and Ramaraj, R.Sustainability assessment of water hyacinth with swine dung for biogas production, methane enhancement, and biofertilizer. Biomass Convers Bior., 2020, 1-12. doi:10.1007/s13399-020-00850-7

3. Qi Xiang., Xiaolong Wei., Zezhou Yang., TonghuiXie., Yongkui Zhang., Defu Li., Xuerong Pan., Xiaolong Liu., Xiang Zhang., and Changhong Yao. Acclimation to a broad range of nitrate strength on a euryhaline marine microalga Tetraselmissubcordiformis for photosynthetic nitrate removal and highquality biomass production. Sci Total Environ., 2021, 781:146687. doi: $10.1016 /$ j.scitotenv.2021.146687

4. Lata, N., and Veenapani, D. Response of water hyacinth manure on growth attributes and yield in Brassica Juncea. J Cent Eur Agric., 2011,12(2):336-343. doi: 10.5513/JCEA01/12.2.921

5. Bhattarai, K., and Conway, D.Impacts of economic growth, transportation, and tourism on the contemporary environment. Contemporary Environmental Problems in Nepal., 2021, 563-662. doi: 10.1007/978-3-030-50168-6_7

6. Gopal, B. Water Hyacinth. Elsevier Science Publishers, Amsterdam, 1987, 477.

7. Jean-Louis Martin., Virginie Maris., Daniel S. Simberloff. The need to respect nature and its limits challenges society and conservation science. PNAS., 2016, 113 (22): 6105-6112. https://doi.org/10.1073/pnas.1525003113

8. Hatton, T. Inquiry under section 46 of the Environmental Protection Act 1986., 2019

9. Anubha Kaushik., Kaushik, C.P. Basics of Environment and Ecology. New Age Inter., Ltd., 2010, Pub.ISBN (13): 978-81-224-2856-8. 
10. Jurgens, A., Bischoff, M. Changing odour landscapes: the effect of anthropogenic volatile pollutants on plant-pollinator olfactory communication. Funct Ecol., 2016, 31(1), 56-64. https://doi.org/10.1111/1365-2435.12774

11. Republic of South Africa. Abstract of Agricultural Statistics. Department of Agriculture, Forestry and Fisheries. Pretoria, 2015.

12. Nieuwoudt. W.L., Backeberg, G.R., and Du Plessis, H.M. The value of water in the South African economy: some implications. Agrekon., 2004, 43(2): 162-183. https://doi.org/10.1080/03031853.2004.9523643

13. DilyanSasaqi., Pranoto., and Prabang Setyono. Estimation of water losses through evapotranspiration of Water Hyacinth (Eichhornia crassipes). J Sustain Agric., 2019, 34(1):86-100. http://dx.doi.org/10.20961/carakatani.v34i1.28214

14. Lisa, A., Wainger, Nathan, E., Harms, Cedric Magen., Dong Liang., Genevieve, M., Nesslage., Anna, M. McMurray. and Al F Cofrancesco.Evidence-based economic analysis demonstrates that ecosystem service benefits of water hyacinth management greatly exceed research and control costs. Peer J., 2018, $1-23$.

doi: $10.7717 /$ peerj. 4824

15. Tanushree., Bhawana Chanana. and Sabina Sethi. Water hyacinth: A wonder weed. Int J Home Sci.,2018, 4(1): 291-294.

16. Adrian E.Williams. Water Hyacinth. Wiley Online Library. Van Nostrand's Scientific Encyclopedia, 2006.

17. Bicudo, D.C., Fonseca, B.M., Bini, L.M., Crossetti, L.O., Bicudo, C.E.M., Araújo-Jesusm T. Undesirable side-effects of water hyacinth control in a shallow tropical reservoir. Freshw Biol.,2007, 52: $1120-1133$. https://doi.org/10.1111/j.1365-2427.2007.01738.x

18. Never Mujere. Water Hyacinth: Characteristics, Problems, Control Options, and Beneficial Uses. Impact of Water Pollution on Human Health and Environmental Sustainability. IGI Global publisher of timely knowledge, 2015.

19. Tim van Emmerik, and Anna Schwarz. Plastic debris in rivers. WileyInterdisciplinaryReviews:WaterpublishedbyWileyPeriodicals,Inc. 2019, 7(1). 1-24.

20. O’Sullivan, L., Murphy, B., McLoughlin, P., Duggan, P., Lawlor, P.G., Hughes, H. and Gardiner, G.E. Prebiotics from Marine Macroalgae for Human and Animal Health Applications.Mar Drugs., 2010, 8(7): 2038-2064.

doi: $\underline{10.3390 / \mathrm{md} 8072038}$

21. Posmyk, M.M. and Szafrańska, K. Biostimulators: a new trend towards solving an old problem, Front. Plant Sci., 2016, 7: 7-48. https://doi.org/10.3389/fpls.2016.00748

22. Gunnarsson, C,C, and Petersen, C.M.Water hyacinths as a resource in agriculture and energy production: a literature review. Waste Manag., 2007, 27(1): 117-129.

doi: 10.1016/j.wasman.2005.12.011 
23. Ngoroyemoto, N., Gupta, S., Kulkarni, M.G., Finnie, J.F. and Van Staden, J. Effect of organic biostimulants on the growth and biochemical composition of Amaranthushybridus L., S Afr J Bot.,2019, 124: 87-93. https://doi.org/10.1016/j.sajb.2019.03.040

24. Abdullahi, I.N., Chuwang, P.Z. and Isah, A.D. Effect of biofertilizer application on growth of (Vitellaria paradoxa) seedlings. J Res Environ Sci Toxicol.,2012, 1(11): 294-297.

25. Du Jardin, P. (2015). Plant biostimulants: definition, concept, main categories and regulation. Scientia Hortic., 196: 3-14.

https://doi.org/10.1016/j.scienta.2015.09.021

26. Yakhin, O.I., Lubyanov, A.A., Yakhin, I.A. and Brown, P.H. Biostimulants in plant science: a global perspective. Front Plant Sci., 2017, 7(2049): 1-32.

https://doi.org/10.3389/fpls.2016.02049

27. Drobek, M., Frąc M. and Cybulska, J. Plant biostimulants: importance of the quality and yiled of horticultural crops and the improvement of plant tolerance to abiotic stress-a review. Agronomy., 2019, 9(6): 335.

https://doi.org/10.3390/agronomy9060335

28. Vivian Pupo de Oliveira Machado., Ana Claudia Pacheco, and Marcia Eugenia Amaral Carvalho. Effect of biostimulant application on production and flavonoid content of marigold (Calendula officinalis L.) Rev Ceres., 2014, 61(6): 983-988.

doi: 10.1590/0034-737X201461060014

29. Baldermann, S., Blagojević, L., Frede, K., Klopsch, R., Neugart, S., Neumann, A., Ngwene, B., Norkeweit, J., Schröter, D., Schröter, A., Schweigert, F.J., Wiesner, M. and Schreiner, M. Are neglected plants the food for the future?.Crit Rev in Plant Sci., 2016, 35(2):1-14. doi: $\underline{10.1080 / 07352689.2016 .1201399}$

30. Tejada M, Benitez C, Parrado J (2011) Application of biostimulants in benzo(a) pyrene polluted soils: short-time effects on soil biochemical properties. Appl Soil Ecol 50: 21-26. doi:10.1016/j.apsoil.2011.08.002

31. Tejada, M., Garcia-Martinez, A.M., Gomez, I. and Parrado, J. (2010). Application of MCPA herbicide on soils amended with biostimulants: short-time effects on soil biological properties. Chemosphere., 80: 1088-1094.

doi: 10.1016/j.chemosphere.2010.04.074

32. Tejada M, Rodríguez-Morgado B, Gómez I, Parrado J. Degradation of chlorpyrifos using different biostimulants/ biofertilizers: effects on soil biochemical properties and microbial community. Appl Soil Ecol., 2014, 84: 158-165. doi: $\underline{10.1016 / j . a p s o i l .2014 .07 .007}$

33. Rodríguez-Morgado, B., Gómez, I., Parrado, J., García, C., Hernández, T. and Tejada, M. Accelerated degradation of PAHs using edaphic biostimulants obtained from sewage sludge and chicken feathers. $\mathrm{J}$ Hazard Mater., 2015, 300: 235-242.

doi: 10.1016/j.jhazmat.2015.05.045 
34. ShahabaldinRezania., MohanadossPonraj., Mohd Fadhil Md Din., Ahmad Rahman Songip., Fadzlin Md Sairan. and ShreeshivadasanChelliapan. The diverse applications of water hyacinth with main focus on sustainable energy and production for new era: An overview. Renewable and Sustainable Energy Reviews., 2015a, 41: 943-954.

DOI: 10.1016/j.rser.2014.09.006

35. Mangrich, A.S., Cardoso, E.M.C., Doumer, M.E., Romão, L.P.C., Vidal, M., Rigol, A. and Novotny, E.H. Improving the Water Holding Capacity of Soils of Northeast Brazil by Biochar Augmentation. American Chemical Society Downloaded by Antonio Mangrich. In Water Challenges and Solutions on a Global Scale; Loganathan, et al.; ACS Symposium Series; American Chemical Society: Washington, DC., 2015, 339-354.

36. Ingole, N.W. and Bhole, A.G. Utilization of water hyacinth relevant in water treatment and resource recovery with special reference to India.J Water Supply Res T.,2002, 51(5): 283-295.

37. ShahabaldinRezania., MohanadossPonraj., AmirrezaTalaiekhozani., Shaza Eva Mohamad., Mohd Fadhil Md Din., Shazwin Mat Taib., Farzaneh Sabbagh and Fadzlin Md Sairan. Perspectives of phytoremediation using water hyacinth for removal of heavy metals, organic and inorganic pollutants in wastewater. J Environ Manage., 2015, 163(1): 125-133.

doi: 10.1016/j.jenvman.2015.08.018.

38. Ting WHT., Tan IAW., Salleh SF. and Wahab, N.A. Application of water hyacinth (Eichhornia crassipes) for phytoremediation of ammoniacal nitrogen: A review. J Water Process Engineering., 2018, 22, 239-249. https://doi.org/10.1016/j.jwpe.2018.02.011

39. ShahabaldinRezania., Mohd Fadhil Md Din., Shaza Eva Mohamad., Johan Sohaili., Shazwin Mat Taib., Mohd Badruddin Mohd Yusof., HesamKamyab., NegisaDarajeh. and Amimul Ahsan. Review on Pretreatment Methods and Ethanol Production from Cellulosic Water Hyacinth. Bioresources., 2017, 12(1): 2108-2124.

40. Anil. K. Sharma., Varruchi Sharma., Vandana Sharma, Sharma J.K. and Raj Singh. Multifaceted potential of Eichhorniacrassipes (Water hyacinth) ladened with numerous value aided and therapeutic properties. Plant Archives., 2020, 20(2):2059-2065.

41. Ogunlesi, M., Okiei, W., Azeez, L., Obakachi, V., Osunsanmi, M. and Nkenchor, G. (2010). Vitamin C contents of tropical vegetables and foods determined by voltammetric and titrimetric methods and their relevance to the medicinal uses of plants. Int J Electrochem Sci., 5: 105-115.

42. Bodo, R., Azzouz, A. and Hausler, R. Antioxidative activity of water hyacinth components. Plant Sci: anInt J Exp Plant Biol.,2004, 166(4): 893-899.

doi: $10.1016 /$ j.plantsci.2003.12.001

43. Lalitha, P. and Jayanthi, P.Antiaging activity of the skin cream containing ethyl acetate extract of Eichhornia crassipes (Mart.) solms. Int J Pharm Tech Res., 2014, 6(1): 29-34.

44. Aboul-Enein, A.M., Shanab, S.M.M., Shalaby, E.A., Zahran, M.M., Lightfoot, D.A. and El-Shemy, H.A.Cytotoxic and antioxidant properties of active principals isolated from water hyacinth against four cancer cells lines. BMC Complement. Altern Med., 2014, 14(397): 1-11. 
45. Jasmine, S., Sankarapandian, V., Natesan, V., Krishnamoorthy, R., and Thangavelu, A. Applications of Microbes in Human Health. In: Inamuddin, Ahamed M.I., Prasad R. (eds) Application of Microbes in Environmental and Microbial Biotechnology.Microb. Biotechnol.,2022,https://doi.org/10.1007/978$\underline{981-16-2225-0 \_11}$ 